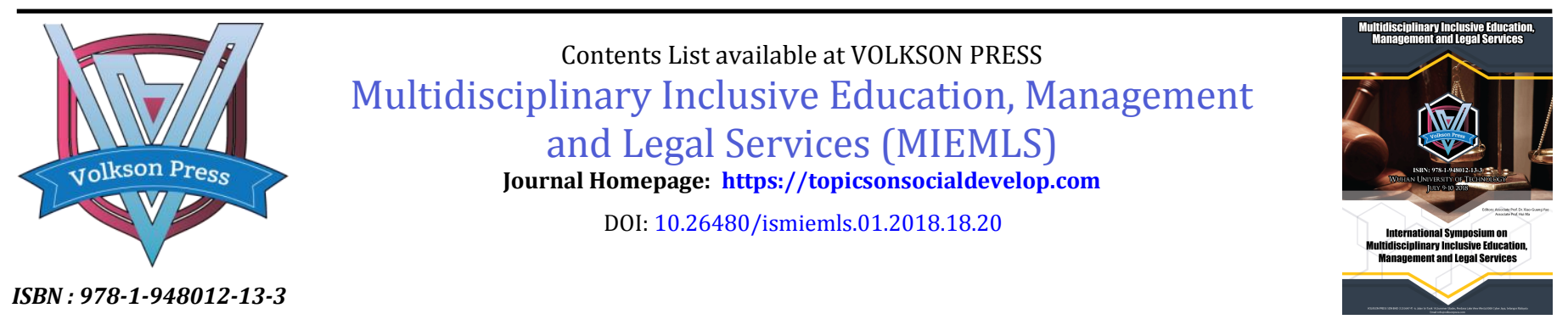

\title{
RESEARCH ON INTELLECTUAL PROPERTY PROTECTION CLAUSES IN SINO FOREIGN INVESTMENT AGREEMENTS
}

\author{
Cao Chen* \\ College of Arts and Law, Wuhan University of Technology, Wuhan Hubei, China \\ *Corresponding Author email: 1123012018@qq.com
}

This is an open access article distributed under the Creative Commons Attribution License, which permits unrestricted use, distribution, and reproduction in any medium, provided the original work is properly cited.

\section{ARTICLE DETAILS}

\section{Article History:}

Received 26 June 2018 Accepted 2 July 2018

Available online 1 August 2018

\section{ABSTRACT}

In the IIAs signed by China, the Agreement among the Government of Japan, the Government of the Republic of Korea and the Government of the People's Republic of China for the Promotion, Facilitation and Protection of Investment is the first agreement expressly providing for the protection of intellectual property rights, and the Contracting Party shall fulfill its obligation of protection in accordance with Article 9, which is a supplement to the treatment of investors and safeguards the implementation of the obligations of the articles from the content and mechanism. It will guide the IPR protection in future Sino-Foreign investment agreements.

\section{KEYWORDS}

Foreign Investment, intellectual property, investment treatment, The Belt and Road Initiative.

\section{INTRODUCTION}

With the time's request of the Belt and Road strategy and the comprehensive opening-up new pattern, the level of China's opening up has deepening in international investment agreements, and the protection of intellectual property is more and more important. It is necessary to strengthen and protect the intellectual property rights in the international investment agreement.

\subsection{Present situation}

So far, China has signed 145 BITs, 14 FATs [1,2]. In many Chinese and foreign investment agreements, most of the agreements have clearly pointed out in the chapter on the meaning of "investment" (the scope of application) that "investment" includes the specific rights related to intellectual property rights, such as copyrights, industrial property rights, technical process, registered trademarks, trade names and goodwill. But in these IIAs (International Investment Agreements), only the Agreement among the Government of Japan, the Government of the Republic of Korea and the Government of the People's Republic of China for the Promotion, Facilitation and Protection of Investment (hereinafter referred to as the China-Japan-Korea Investment Agreement) clearly stipulates the provisions on the protection of intellectual property rights. There is no doubt that when there is an international investment dispute involving intellectual property, the right holder cannot directly invoke the provisions of the intellectual property protection and can only use the terms "NT (national treatment", "MFN (most-favored-nation) treatment", "FET (fair and equitable treatment)", and "Expropriation of Compensation clause". However, there are some limitations and definitions in the practical application of these Provisions, which often lead to different cases.

\subsection{Content of the terms of intellectual property}

China-Japan-Korea Investment Agreement is the only multilateral agreement that stipulates the protection clause of intellectual property rights, signed in May 13, 2012, entered into force on May 17, 2014, and is still valid. Article 9 of the Agreement is a provision specifically providing for intellectual property, which contains the following items:"
1. (a) Each Contracting Party shall, in accordance with its laws and regulations, protect intellectual property rights. (b) Each Contracting Party shall establish and maintain transparent intellectual property rights regimes, and will, under the existing consultation mechanism on intellectual property, promote cooperation and communications among the Contracting Parties in the intellectual property field.

2. Nothing in this Agreement shall be construed so as to derogate from the rights and obligations under international agreements in respect of protection of intellectual property rights to which two or more Contracting Parties are parties.

3. Nothing in this Agreement shall be construed so as to oblige a Contracting Party to extend to investors of another Contracting Party and their investments treatment accorded to investors of the third Contracting Party or of a non-Contracting Party and their investments by virtue of international agreements in respect of protection of intellectual property rights, to which, respectively, the first-mentioned Contracting Party and the third Contracting Party and the first-mentioned Contracting Party and the non-Contracting Party are parties [3]."

According to the Article 9, the obligations of Contracting Parties can be summarized as follows:

(1) Contracting Party shall protect it in accordance with the law. The original text is "law and regulation", therefore, this obligation refers to the use of domestic law for protection. In our country, it mainly includes the copyright law of the People's Republic of China, the patent law of the People's Republic of China and the People's Republic of China trademark law, as well as the judicial interpretations and local regulations related to the intellectual property right.

(2) To establish a system of transparency and cooperation. This obligation is to better resolve disputes, establish transparent intellectual property system, keep open and fair, and maintain exchanges and consultations.

(3) The rights and obligations under other international agreements must 
not be derogated. This Agreement, which is a multilateral agreement signed by the three countries of China, Japan, and Korea, is only effective between the Contracting Parties. Any rights and obligations under the Agreement are not affected by other agreements. The Contracting Parties, while complying with the Agreement, do not affect the country's due rights and obligations under other international agreements.

(4) Do not give the Contracting Parties the other investment agreement treatment. This obligation means that, when a Contracting Party and the third Contracting Party or non- Contracting Party have signed an international agreement on the protection of intellectual property rights, the parties are not obliged to give the treatment of this Agreement to the other Contracting Party investors and their investment in the China-JapanKorea Investment Agreement.

The first two items are obligations, and the latter two are obligations of omission. After signing the Agreement, the Contracting Party should fulfill the obligations of action and omission according to the Agreement so as to protect and promote the development of the intellectual property system among the Contracting Parties.

\section{RESEARCH ON THE PROBLEM}

\subsection{Whether intellectual property belongs to the investment}

This is the first thing to be determined before dealing with disputes. In theory, foreign investment involves the transfer of tangible or intangible assets from one country to another for the purpose of their use in that country to generate wealth under the total or partial control of the owner of the assets [4]. Intellectual property belongs to intangible property and should belong to investment. In fact, whether the intellectual property rights belong to the form of investment, each Agreement are different, so it is necessary to determine cases in handling specific cases.

In terms of the China-Japan-Korea Investment Agreement, Article 1 (Investment Definitions) clearly acknowledges: " the term "investments" means every kind of asset that an investor owns or controls, directly or indirectly, which has the characteristics of an investment, such as the commitment of capital or other resources, the expectation of gain or profit, or the assumption of risk. Forms that investments may take include:(f) intellectual property rights, including copyrights and related rights, patent rights and rights relating to utility models, trademarks, industrial designs, layout-designs of integrated circuits, new varieties of plants, trade names, indications of source or geographical indications and undisclosed information." Therefore, under the Agreement, intellectual property belongs to investment, and when the investor of the Contracting Party use intellectual property to invest in each Contracting Party, the Host Country must protect the investor in accordance with the content of the Article 9 of the Agreement.

As for other international investment agreements, whether intellectual property rights should be regarded as the object of investment cannot be generalized. However, by concluding all the international investment agreements that our country has signed, most of the agreements clearly explain the following: " copyrights, industrial property rights, technical process, registered trademarks, trade names and goodwill ", which means that more and more countries have gradually attached importance to it and have risen the intellectual property rights to the scope of investment protection of international investment agreements.

\subsection{Other provision solutions}

Because only China-Japan-Korea Investment Agreement clearly stipulates the provisions of intellectual property protection, that means that in the international investment agreement, the protection of intellectual property rights is obviously weak and not enough, and it needs to be perfect.

In the international investment arbitration, there are no intellectual property cases involving Chinese investors, but China still needs to attach importance to the protection of intellectual property in international investment and establish corresponding protection provisions and protection mechanism of intellectual property.

So far, there are three international investment arbitration cases involving intellectual property rights which have been closed. They are "2010 Philip Morris v. Uruguay", "2011 Philip Morris v. Australia" and "2013Eli Lilly v. Canada" [4-6]. In these three cases, the legal basis for the right to relief of intellectual property is mainly "FET (fair and equitable treatment)" and "Expropriation and Compensation clause". Under the investment agreement, if the intellectual property belongs to the form of investment, it is entitled to all the treatment of investment protection, including the NT, MFN, FET, the Expropriation and Compensation clause, and so on. This is the substantive measure of the protection of intellectual property in the investment agreement [7].

However, as the legal basis, these investment treatments depend on the interpretation of the arbitration tribunal and the result is uncertain and unpredictable. Therefore, the direct establishment of the intellectual property protection clause in the investment agreement will help the intellectual property dispute to be better and faster solved.

The Article 9 in the China-Japan-Korea Investment Agreement, as the only protection clause in the investment agreement signed by China, has certain guidelines and will be a good model. Its greatest advantage lies in the clear legal basis for resolving intellectual property disputes. If there is uncertainty in the interpretation of "FET" and "Expropriation and Compensation clause", the provisions on intellectual property protection set up in the agreement should be transparent in content and procedure, more specific and guiding. The first two obligations of the Article 9, which have exactly pointed out the legal basis, have also promoted the improvement and perfection of the intellectual property system in the Contracting Party.

At present, the international legal mechanism that can provide practical relief for intellectual property protection has WTO dispute settlement mechanism and ISDS (Investor-State Dispute Settlement) mechanism. The dispute settlement of WTO is a procedure of public law nature, which only accepts disputes between nations [8]. Therefore, in contrast, the ISDS mechanism between investors and Host Countries is more convenient. On the other hand, the intellectual property holders can also use the host country's domestic litigation in the way of relief, but compared with the international settlement mechanism, the transparency of domestic litigation is low.

It is worth celebrating that on September 19, 2017, the China International Economic and Trade Arbitration Commission issued the Arbitration Rules for International Investment Disputes and implemented it on October 1st. This marks the international investment arbitration as the main way to solve the investment disputes between the investor and the host country, and the formulation of its rules fills the gap in the field of international investment arbitration in China. This arbitration method provides an optional dispute resolution mechanism for the State to sign multiple bilateral investment agreements [9]. It is of great significance to provide an international investment dispute arbitration service platform for Chinese enterprises to "go out" [10]. This measure safeguards the perfection of the terms of intellectual property protection from the mechanism and will play a more convenient role in the settlement of intellectual property disputes in the future.

\section{CONCLUSION}

The China-Japan-Korea Investment Agreement is the first agreement on the provision of intellectual property protection in IIAs, which is signed by China. The Contracting Party should fulfill the obligation of intellectual property protection under the Article 9 of the agreement. It recognizes that intellectual property is the legal form of investment. Therefore, the intellectual property holders enjoy all the treatment of investment protection. Sometimes the content of the investment treatment explained by the arbitral tribunal is not certain, so it is really significant for China to set up a provision of intellectual property, which also plays a guiding role in the signing of other international investment agreements. While the 
implementation of safeguards from the Provision content and mechanism, there is a reason to believe that under the "The Belt and Road" strategy the protection of intellectual property rights in China will gradually improve!

\section{REFERENCE}

[1] Xiaoping, T. 2016. The path and legal effect of intellectual property protection in international investment agreement : from the perspective of " Eli Lilly v. Canada ". Political Law, 1, 97-104.

[2] Jing, Q. 2016. Application of ISDS mechanism for overseas intellectual property protection. Intellectual Property, 11, 112-118.

[3] UNCTAD. 2018. Investment Policy, bilateral investment treaties signed by China, $\quad / 5 / 29$ http://investmentpolicyhub.unctad.org/IIA/CountryBits/42\#iiaInnerMe $\mathrm{nu}$

[4] China FTA Network. 2018. Free Trade Agreements signed by China, 5/29, http://fta.mofcom.gov.cn/english/index.shtml

[5] UNCTAD. 2012. Investment Policy, Treaties with Investment Provisions signed by China, 2018/5/29 China - Japan - Korea, Republic of Trilateral
http://investmentpolicyhub.unctad.org/IIA/country/42/treaty/3302

[6] Sàrl, P.M.B., Philip Morris Products S.A., Abal Hermanos, S.A.V. 2016. The Oriental Republic of Uruguay, Decision on the Rectification of the Award (26/SEP/2016) ,ICSID Case No. ARB/10/7,https://www.italaw.com/sites/default/files/casedocuments/italaw7585.pdf

[7] Philip Morris Asia Limited v. 2015. The Commonwealth of Australia, Award on Jurisdiction and Admissibility (17/Dec /) https://www.italaw.com/sites/default/files/casedocuments/italaw7303_0.pdf

[8] Eli Lilly and Company v. 2017. The Government of Canada, Final Award (16/ March/2017), UNCITRAL, ICSID Case No. UNCT/14/2, https://www.italaw.com/sites/default/files/casedocuments/italaw8546.pdf

[9] Lili, W. 2017. The solution to the international investment dispute has a "China plan", News http://www.fx361.com/page/2017/1229/2633302.shtml

[10] Sornarajah, M. 2010. The international law on foreign investment. Cambridge University Pre. 